\title{
Magnetic Properties of High Coercivity Melt-Spun Didymium-Fe-Co-Nb-Y-B System Ribbons and Their Bonded Magnets
}

\author{
H. Yamamoto, K. Furusawa, and N. Miyashita \\ School of Science and Technology, Meiji Univ., 1-1-1, Higashimita, Tama-ku, Kawasaki 214-8571, Japan
}

\begin{abstract}
Melt-spun ribbons of Didymium-Fe-Co-Nb-Y-B system alloys were prepared by the single-roller liquid rapid-quenching method. The effects of $\mathrm{Y}$ addition, wheel velocity, and heat treatment on the magnetic properties were investigated. The optimum preparation conditions of the compounds were as follows: composition Didymium ${ }_{12.5} \mathrm{Fe}_{69.8} \mathrm{Co}_{10} \mathrm{Nb}_{1} \mathrm{Y}_{0.7} \mathrm{~B}_{6}$; wheel velocity $20.0 \mathrm{~m} / \mathrm{s}$; heat treatment $650^{\circ} \mathrm{C}$ for 10 min. Magnetic properties of this ribbon were $(\mathrm{BH})_{\max }=126.4 \mathrm{~kJ} / \mathrm{m}^{3}$ and $\mathrm{H}_{\mathrm{cJ}}=1409.0 \mathrm{kA} / \mathrm{m}$. The value of $(\mathrm{BH})_{\max }$ for the isotropic compression molding Didymium ${ }_{12.5} \mathrm{Fe}_{69.8} \mathrm{Co}_{10} \mathrm{Nb}_{1} \mathrm{Y}_{0.7} \mathrm{~B}_{6}$ bonded magnet prepared by using the ribbons annealed at $650^{\circ} \mathrm{C}$ for $10 \mathrm{~min}$ was $66.3 \mathrm{~kJ} / \mathrm{m}^{3}$ and the density was $6.1 \mathrm{Mg} / \mathrm{m}^{3}$. The irreversible loss of this bonded magnet was $-3.58 \%\left(\right.$ at $\left.150^{\circ} \mathrm{C}\right)$. It was found that the irreversible loss was improved by $\mathrm{Y}$ addition.
\end{abstract}

Key words: Didymium-Fe-Co-Nb-Y-B alloy, melt-spun ribbons, magnetic properties, bonded magnets, temperature characteristics

\section{高保磁力 Didymium-Fe-Co-Nb-Y-B 系急冷薄帯 並びにそれらボンド磁石の磁気特性}

\author{
山元 洋・古澤 綱・宮下 尚之 \\ 明治大学理工学部，川崎市多摩区東三田 1-1-1（广214-8571）
}

\section{1. 緒 言}

近年，車載用の小型モー夕は大変多く生産されているが，それ らに使用される磁石材料は熱安定性の良好なものが要求される. また，希土類一鉄一ボロン系合金では高性能な急冷薄帯が種々開 発され 1) 5)，ボンド磁石として利用されている.

先に著者らはDi-Fe-Co- $\mathrm{Nb}-\mathrm{B}{ }^{6), 7)}$ 系やDi-Fe-Co-Nb-V-B ${ }^{8,9)}$ 系急 冷薄帯ボンド磁石の報告をした. 本研究では，さらなる温度特性 の向上を目的として，Fe-Cr系のカンタル線等でイットリウム( $\mathrm{Y})$ を少量添加したときの発熱体としての耐熱性向上はよく知られて いるので, Di-Fe-Co-Nb-B合金にイットリウム (Y) の少量の添加 を試夕, 組成, 急冷条件, 熱処理条件等が Di-Fe-Co- $\mathrm{Nb}-\mathrm{Y}-\mathrm{B}$ 系急冷 薄帯合金の磁気的・物理的特性に与える影響を詳細に検討した. また, 得られた薄帯を用いて等方性圧縮成形ボンド磁石を作製し, それらの諸特性についても詳細に検討した. なお, Didymiumを 用いた理由としては, Pr並びにNd単体を用いるより工業的に安価 なためである.

\section{2. 実 験 方 法}

実験に用いた原材料は Di-Fe 合金, Co, Nb, Y, B である. Di-Fe 母合金はNd が 66.7 wt.\%，Pr が 19.1 wt.\%，Fe が 14.1 wt.\%の ものを用いた．また，各原子の構成比率より Didymium の分子量 を 143.5 とした. 以後, 組成式で Didymium をDi と表記する.

急冷薄帯作製に用いた組成はDi ${ }_{12.5} \mathrm{Fe}_{70.5 \mathrm{x}} \mathrm{Co}_{10} \mathrm{Nb}_{1} \mathrm{Y}_{\mathrm{x}} \mathrm{B}_{6}$ として, $\mathrm{Y}$ 含有量 $x$ を 0 ～ 1.0 at.\%と変化させた. これらの組成は著者らの先 の報告, Di-Fe-Co- $\mathrm{Nb}$-B系急冷薄帯の研究7 より決定した. 上記の 各組成の母合金は，真空吸い上げ法により棒状インゴットを作製 した．また，薄帯は片ロール液体急冷法により作製した．片ロー ル液体急冷法は母合金の酸化防止のためArガス䨌井気中において,
母合金を石英射出管に入れ, 高周波誘導炉で溶解した後に, 銅製 にCrメッキを施した回転ロール上に射出するという工程で行った. このとき石英射出管はオリフィス径が $0.5 \mathrm{~mm}$ のものを使用した. また薄帯作製時の条件は，ロール径 $300 \mathrm{~mm}$, ロール周速度 15.0 $\sim 22.5 \mathrm{~m} / \mathrm{s}$ で，射出時には高純度 $\mathrm{Ar}$ ガスを用いて射出ガス圧を 38 $\mathrm{kPa}$ 一定とした. 熱処理は, 赤外線ゴールドイメージ炉を用いて高 純度 $\mathrm{Ar} カ$ ズ雰囲気中で行った. 熱処理温度は $575 \sim 675^{\circ} \mathrm{C}$, 熱処理 時間は $0 \sim 15 \mathrm{~min} の$ 範囲で変化させた. また, 昇温時間は所定の 温度まで $3 \mathrm{~min}$ 一定とした。

薄帯試料の磁気特性, キュリー温度および温度特性は, 振動試 料型磁力計 (VSM) を用いた. 薄帯試料の測定は, 全て $4.8 \mathrm{MA} / \mathrm{m}$ のパルス着磁後に測定した. 結晶構造は粉末 X 線回折法により測 定した. また, 非結晶試料の結晶化温度は, 示差走査熱量測定計 (DSC) を用いて測定した.

ボンド磁石の作製法は, 薄帯試料を最適条件で熱処理後, 結晶 化されたものを $150 \mu \mathrm{m}$ 以下に粉砕し, 結合剤として而熱性エポ キシ樹脂（2.5 wt.\%）を混合・攪拌し，980 MPaの圧力で圧縮成 形した後, $200^{\circ} \mathrm{C} \times 1 \mathrm{~h}$ のキュア処理を行った. ボンド磁石の磁気 特性は $4.8 \mathrm{MA} / \mathrm{m}$ のパルス着磁後に高感度自記磁束計を用いて測 定した. また, ボンド磁石の不可逆減磁率はデジタルフラックス メータを用いて測定した.

\section{3. 実験結果並びに考察}

\section{1 組成・作製条件による磁気特性の変化}

Fig.1 はDi ${ }_{12.5} \mathrm{Fe}_{69.8} \mathrm{Co}_{10} \mathrm{Nb}_{1} \mathrm{Y}_{0.7} \mathrm{~B}_{6}$ 組成急冷薄帯をロール周速度 $20.0 \mathrm{~m} / \mathrm{s}$ で作製したときのDSC曲線を示したものである. 測定は 急冷薄帯を粉末にしたものを約 $20 \mathrm{mg}$ 用いた. 眓から知られるよ

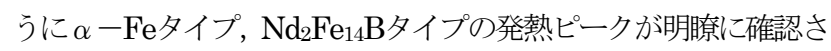




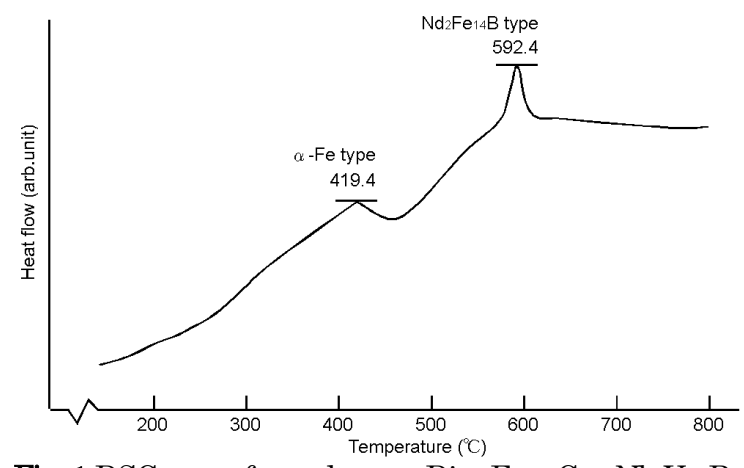

Fig. 1 DSC curve for melt-spun $\mathrm{Di}_{12.5} \mathrm{Fe}_{69.8} \mathrm{Co}_{10} \mathrm{Nb}_{1} \mathrm{Y}_{0.7} \mathrm{~B}_{6}$ alloy powders.

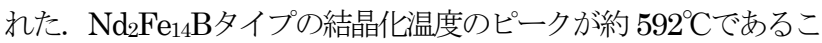
とから, 今後この系の熱処理は $575^{\circ} \mathrm{C}$ 以上で行った. また, 相の 同定は各温度付近て熱処理し, 急冷後X線回折法を行い決定した.

Fig.2 にDi12.5 $\mathrm{Fe}_{70.5 \mathrm{x}} \mathrm{Co}_{10} \mathrm{Nb}_{1} \mathrm{Y}_{\mathrm{x}} \mathrm{B}_{6}$ 組成急冷薄帯において, Y含有 量 $x$ を $0 \sim 1.0$ at.\%の範囲で変化させたときの磁気特性を示す.こ のときの作製条件は, ロール周速度 $20.0 \mathrm{~m} / \mathrm{s}$, 熱処理温度 $650^{\circ} \mathrm{C}$, 熱処理時間 $10 \mathrm{~min}$ とした. 図から知られるように, $\mathrm{Y} の$ 含有量 $x$ の増加に伴い， $H_{\mathrm{cJ}}$ は上昇する傾向を示した. また， $(B H)_{\text {max }}$ は $x=$ 0.7 まで緩やかに増加し, その後急激に減少寸る傾向を示した.

$H_{\mathrm{cB}}$ においてはYの含有量 $\mathrm{x} の$ 変化による影響はあまり見られなか った. 以上の結果から， $H_{\mathrm{cJ}}$ が比較的良好な值を示し，Jr， $(B H)_{\text {max }}$ が良好な值を示したY含有量 $x=0.7$ at.\%を本組成の最適量とした。 Y含有量 $x=0.7$ at.\%のとき, $\mathrm{Y}$ 無添加の時と比べ保磁力 $H_{\mathrm{cJ}}$ は約 $27 \%$ 増加した.

続いて，急冷薄帯作製時のロール周速度変化が磁気特性に及ぼ す影響について検討した. Fig.3 はDi12.5Fe69.8Co10 Nb ${ }_{1} \mathrm{Y}_{0.7} \mathrm{~B}_{6}$ 組成 において, 熱処理温度 $650^{\circ} \mathrm{C}$, 熱処理時間 $10 \mathrm{~min}$ 一定で, ロール

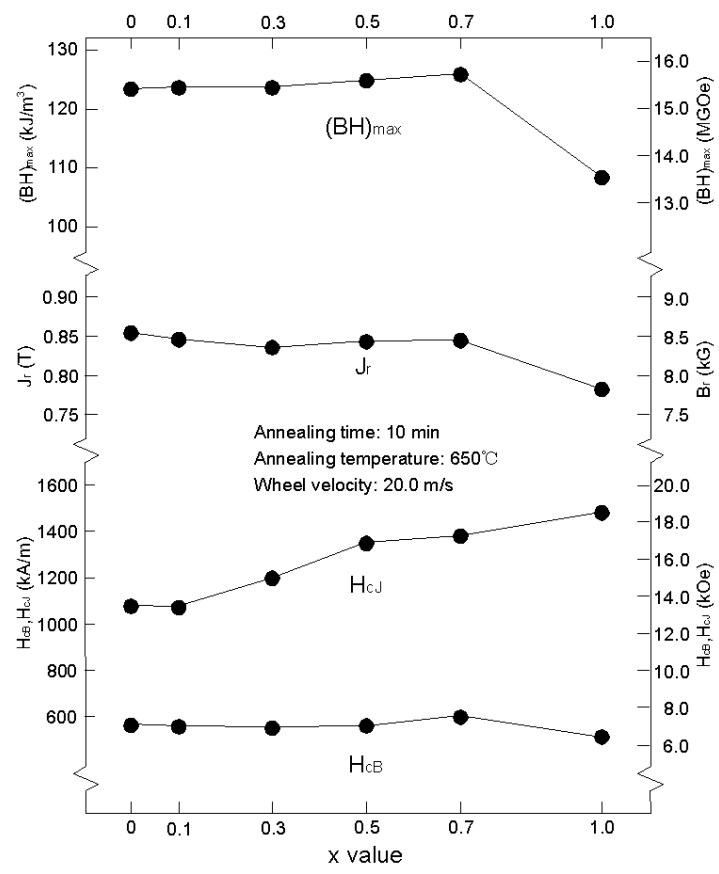

Fig. 2 Magnetic properties of melt-spun $\mathrm{Di}_{12.5} \mathrm{Fe}_{70.5 \times} \mathrm{Co}_{10} \mathrm{Nb}_{1}$ $\mathrm{Y}_{\mathrm{x}} \mathrm{B}_{6}$ alloy ribbons.

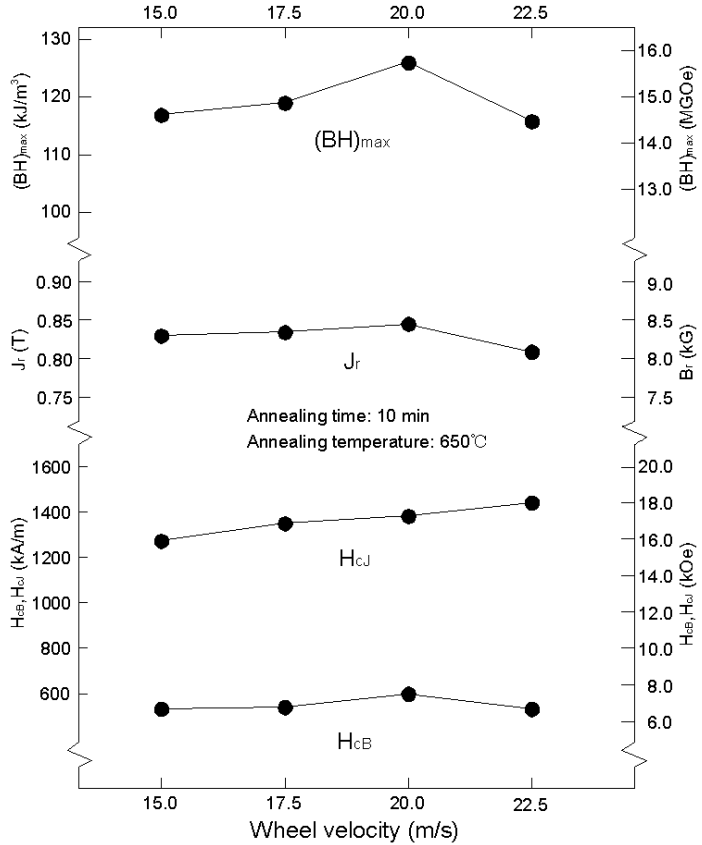

Fig. 3 Effect of the wheel velocity on the magnetic properties of melt-spun $\mathrm{Di}_{12.5} \mathrm{Fe}_{69.8} \mathrm{Co}_{10} \mathrm{Nb}_{1} \mathrm{Y}_{0.7} \mathrm{~B}_{6}$ alloy ribbons.

周速度を 15.0 ～ $22.5 \mathrm{~m} / \mathrm{s}$ まで変化させたときの磁気特性を示した ものである. 図から分かるように， $H_{\mathrm{G}}$ はロール周速度の上昇とと もに増加する傾向を示した。 また，Jr， $H_{\mathrm{cB}} ，(B H)_{\max }$ はロール周 速度 $20.0 \mathrm{~m} / \mathrm{s}$ のとき最大值をとり, その後減少する傾向を示した. 以上の結果から, $(B H)_{\text {max }}$ の值を考慮し, 本組成の最適ロール周速 度は $20.0 \mathrm{~m} / \mathrm{s}$ とした.

次にDi12.5 $\mathrm{Fe} 69.8 \mathrm{Co}_{10} \mathrm{Nb}_{1} \mathrm{Y}_{0.7} \mathrm{~B}_{6}$ 組成急冷薄帯において熱処理条 件の変化が磁気特性に与える影響について検討した. Fig.4 は

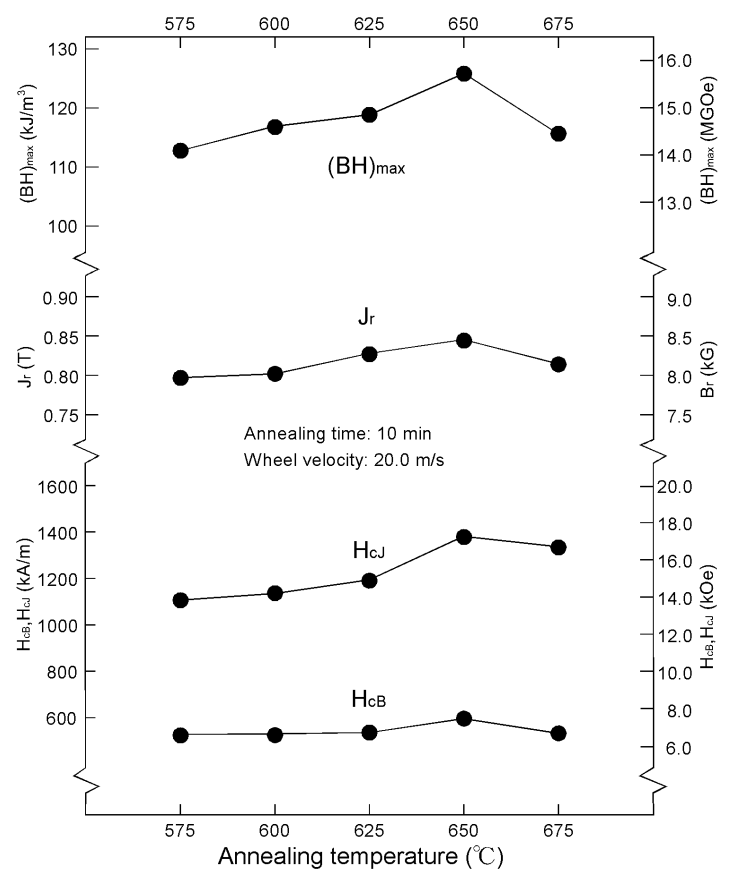

Fig. 4 Effect of the annealing temperature on the magnetic properties of melt-spun $\mathrm{Di}_{12.5} \mathrm{Fe}_{69.8} \mathrm{Co}_{10} \mathrm{Nb}_{1} \mathrm{Y}_{0.7} \mathrm{~B}_{6}$ alloy ribbons. 


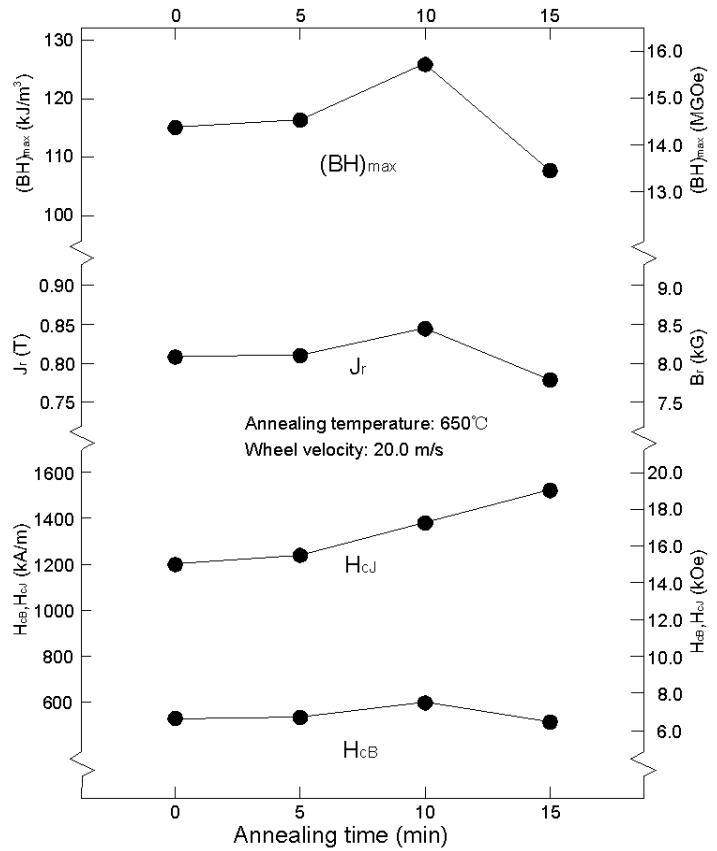

Fig. 5 Effect of the annealing time on the magnetic properties of melt-spun $\mathrm{Di}_{12.5} \mathrm{Fe}_{69.8} \mathrm{Co}_{10} \mathrm{Nb}_{1} \mathrm{Y}_{0.7} \mathrm{~B}_{6}$ alloy ribbons.

Di12.5 $\mathrm{Fe}_{69.8} \mathrm{Co}_{10} \mathrm{Nb}_{1} \mathrm{Y}_{0.7} \mathrm{~B}_{6}$ 組成急冷薄帯において，ロール周速度を $20.0 \mathrm{~m} / \mathrm{s}$ ，熱処理時間を $10 \mathrm{~min}$ 一定とし，熱処理温度を 575〜 $675^{\circ} \mathrm{C}$ まで変化させたときの磁気特性を示したものである. 図から 知られるように $\int_{\mathrm{r}}, H_{\mathrm{cJ}}, H_{\mathrm{cB}},(B H)_{\text {max }}$ はそれぞれ熱処理温度 $650^{\circ} \mathrm{C}$ まで増加し，その後減少寸る傾向を示した．以上の結果より本組

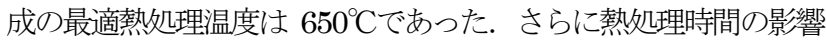
について検討した. Fig.5 は 帯において，ロール周速度を $20.0 \mathrm{~m} / \mathrm{s}$ ，熱処理温度を $650^{\circ} \mathrm{C}$ 一定 とし，熱処理時間を 0〜10 minまで変化させたときの磁気特性を 示したものである. 図から知られるように $(B H)_{\max }, J_{\mathrm{r}}, H_{\mathrm{cB}}$ は熱 処理時間 10 minまで増加し, その後減少する傾向を示した. また, $H_{\mathrm{c} J}$ は熱処理時間が増加するとともに上昇する傾向を示した. 以上 の結果から，(BH) maxの值を考慮し，本組成の最適熱処理時間を 10 minとした.

以上の組成別，ロール周速度別，熱処理温度別，熱処理時間別 による考察から，本実験の範囲で最も高い磁気特性を得た条件は， 組成 $\mathrm{Di}_{12.5} \mathrm{Fe}_{69.8} \mathrm{Co}_{10} \mathrm{Nb}_{1} \mathrm{Y}_{0.7} \mathrm{~B}_{6}$ ， ロール周速度 $20.0 \mathrm{~m} / \mathrm{s}$, 熱処理条 件 $650^{\circ} \mathrm{C} \times 10 \mathrm{~min}$ であることがわかった．以後，この条件を最適 作製条件とした.

最適作製条件で作製した $\mathrm{Di}_{12.5} \mathrm{Fe}_{69.8} \mathrm{Co}_{10} \mathrm{Nb}_{1} \mathrm{Y}_{0.7} \mathrm{~B}_{6}$ 組成急冷薄帯 の減磁曲線をFig.6 に示寸. 磁気特性として, J $=0.85 \mathrm{~T}, H_{\mathrm{cJ}}=$ $1409.0 \mathrm{kA} / \mathrm{m}, H_{\mathrm{cB}}=588.3 \mathrm{kA} / \mathrm{m},(B H)_{\text {max }}=126.4 \mathrm{~kJ} / \mathrm{m}^{3}$ を得た. また角型比 $H_{\mathrm{k}} / H_{\mathrm{c}} \times 100=31.9$ \%であった.

なお，上記の組成はFeをYで置換した組成になっているが， DidymiumをYで置換した $\mathrm{Di}_{11.8} \mathrm{Y}_{0.7} \mathrm{Fe}{ }_{70.5} \mathrm{Co}_{10} \mathrm{Nb}_{1} \mathrm{~B}_{6}$ 組成急冷薄帯 では保磁力 $H_{\mathrm{cJ}}=1262.1 \mathrm{kA} / \mathrm{m}$ であった. Di12.5 Fe69.8 $\mathrm{Co}_{10} \mathrm{Nb}_{1} \mathrm{Y}_{0.7} \mathrm{~B}_{6}$ 組成急冷薄帯と比較すると保磁力は約 $10 \%$ 減少したものの, Y無 添加のDi ${ }_{12.5} \mathrm{Fe}_{70.5} \mathrm{Co}_{10} \mathrm{Nb}_{1} \mathrm{~B}_{6}$ 組成急冷薄帯では $H_{c \mathrm{~J}}=1048.8$ $\mathrm{kA} / \mathrm{m}$ であるため, Yの希土類置換でも保磁力増大が確認された.

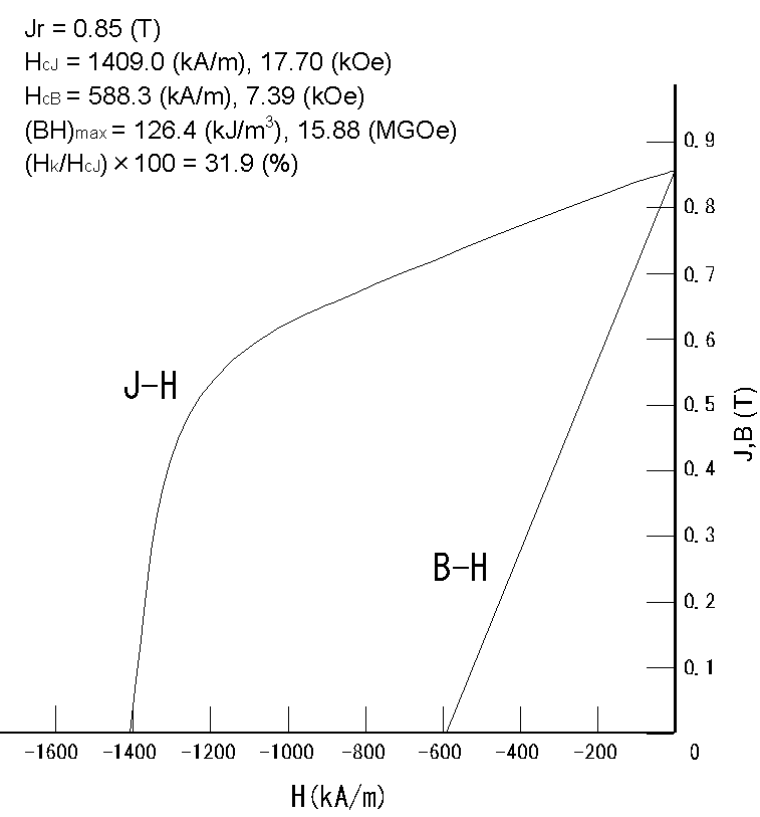

Fig. 6 Demagnetization curves of melt-spun $\mathrm{Di}_{12.5} \mathrm{Fe}_{69.8}$ $\mathrm{Co}_{10} \mathrm{Nb}_{1} \mathrm{Y}_{0.7} \mathrm{~B}_{6}$ alloy ribbons annealed at $650^{\circ} \mathrm{C}$ for $10 \mathrm{~min}$.
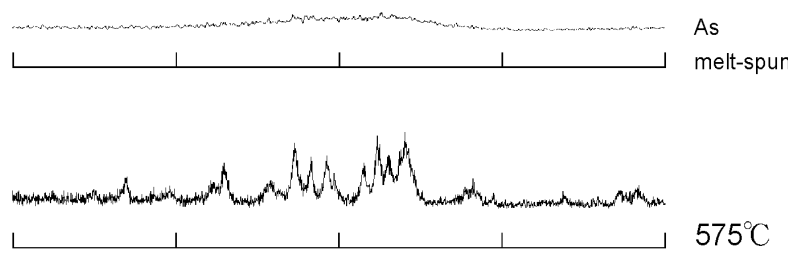
$575^{\circ} \mathrm{C}$

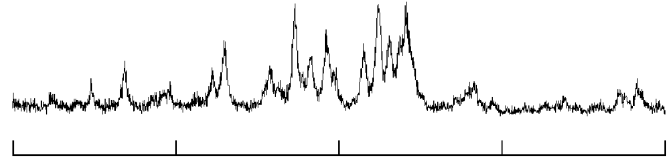
$600^{\circ} \mathrm{C}$

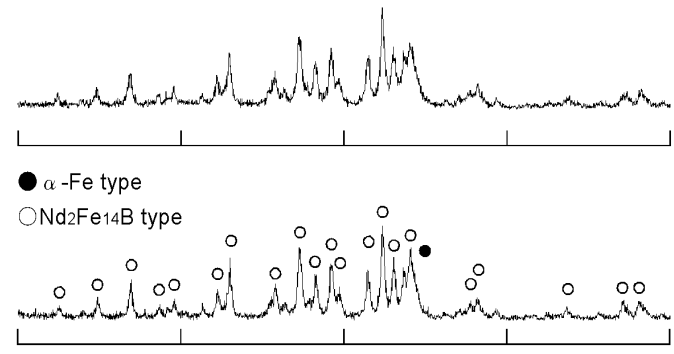
$625^{\circ} \mathrm{C}$

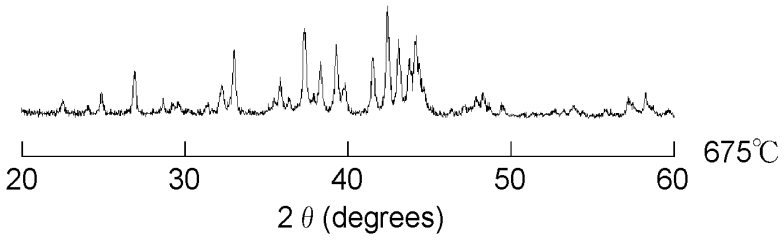

Fig. 7 X-ray diffraction patterns of melt-spun $\mathrm{Di}_{12.5} \mathrm{Fe} 69.8$ $\mathrm{Co}_{10} \mathrm{Nb}_{1} \mathrm{Y}_{0.7} \mathrm{~B}_{6}$ alloy ribbons as a function of the annealing temperature.

$\mathrm{Fe}$ 置換，希土類置換ともにY添加により保磁力 $H_{\mathrm{cJ}}$ が増加すること が知られたが，これらの原因については， $\mathrm{Y}_{2} \mathrm{Fe}_{14} \mathrm{~B} は$ 異方性磁界が 小さく, また後述の組織写真などから考えても微細化されておら ず，化合物の磁気の本質的な特性が変化しているものと思われる. 


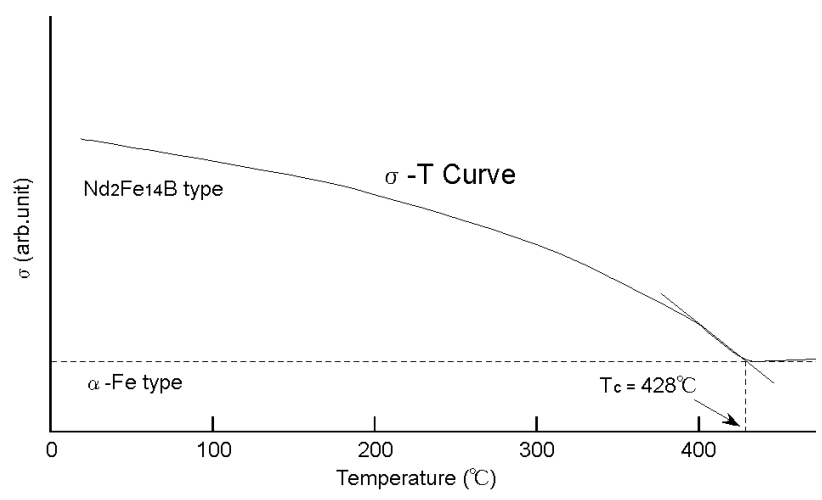

Fig. 8 Temperature dependence of the magnetization of melt-spun $\mathrm{Di}_{12.5} \mathrm{Fe}_{69.8} \mathrm{Co}_{10} \mathrm{Nb}_{1} \mathrm{Y}_{0.7} \mathrm{~B}_{6}$ alloy ribbons annealed at $650^{\circ} \mathrm{C}$ for $10 \mathrm{~min}$.

\section{2 急冷薄帯の $\mathrm{X}$ 線回折図形, 組織及ひ温度特性}

Fig.7 はDi12.5 $\mathrm{Fe}_{69.8} \mathrm{Co}_{10} \mathrm{Nb}_{1} \mathrm{Y}_{0.7} \mathrm{~B}_{6}$ 組成急冷薄帯において熱処理 温度別と急冷後の薄帯についてX線回折図形をまとめたものであ る. 図より，急冷後はほぼアモルファスになっていることが見て 取れる。 また, 各温度別のX線回折図では $\alpha-\mathrm{Fe}$ 型結晶相と $\mathrm{Nd}_{2} \mathrm{Fe}_{14} \mathrm{~B}$ 型結晶相の回折線が見られた。 $\alpha$ - $\mathrm{Fe}$ 型結晶相の回折線 強度は全体から見ると小さいものであった. 熱処理後のX線回折図 形の結果， $\alpha$ - $\mathrm{Fe}$ 型結晶相と $\mathrm{Nd}_{2} \mathrm{Fe}_{14} \mathrm{~B}$ 型結晶相の 2 相が生成され ていることが知られた.

Fig.8 に最適条件で作製されたDi12.5 $\mathrm{Fe}_{69.8} \mathrm{Co}_{10} \mathrm{Nb}_{1} \mathrm{Y}_{0.7} \mathrm{~B}$ 6 組成急 冷薄帯の，160 kA/mの印加磁界で測定した $\sigma$ 一曲線を示す. 図 よりキュリー温度を求めると $T_{\mathrm{c}}=428^{\circ} \mathrm{C}$ なった. またこの図より, 磁化に寄与する結晶相の大まかな割合は, $\mathrm{Nd}_{2} \mathrm{Fe}_{14} \mathrm{~B}$ 型結晶相は $76 \%, \alpha-\mathrm{Fe}$ 型結晶相は $24 \%$ と求められた.

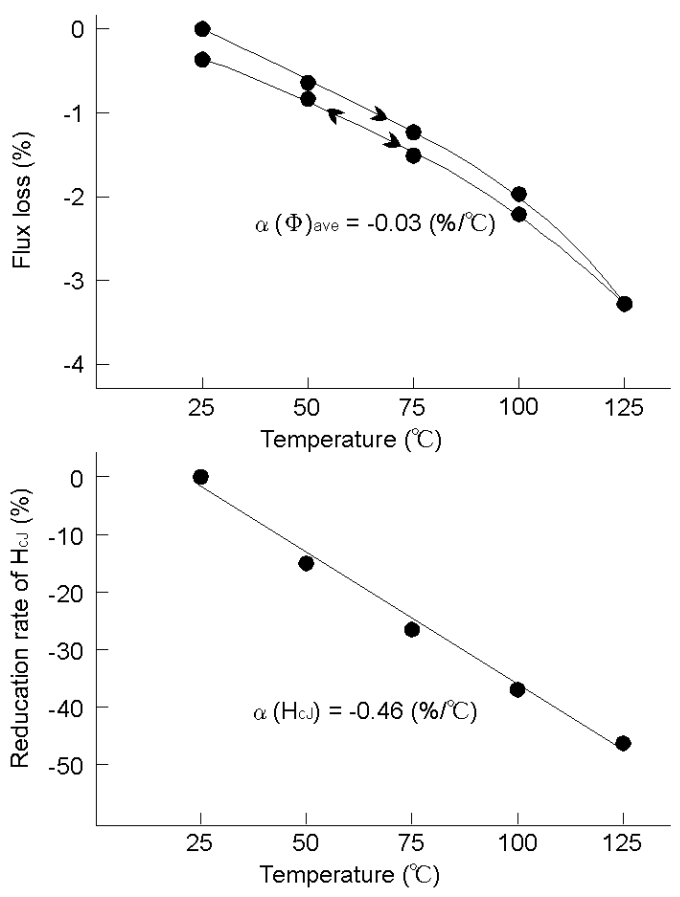

Fig. 9 Temperature dependence of $\Phi$ and $\mathrm{H}_{\mathrm{CJ}}$ of melt-spun $\mathrm{Di}_{12.5} \mathrm{Fe}_{69.8} \mathrm{Co}_{10} \mathrm{Nb}_{1} \mathrm{Y}_{0.7} \mathrm{~B}_{6}$ alloy ribbons annealed at $650^{\circ} \mathrm{C}$ for $10 \mathrm{~min}$.

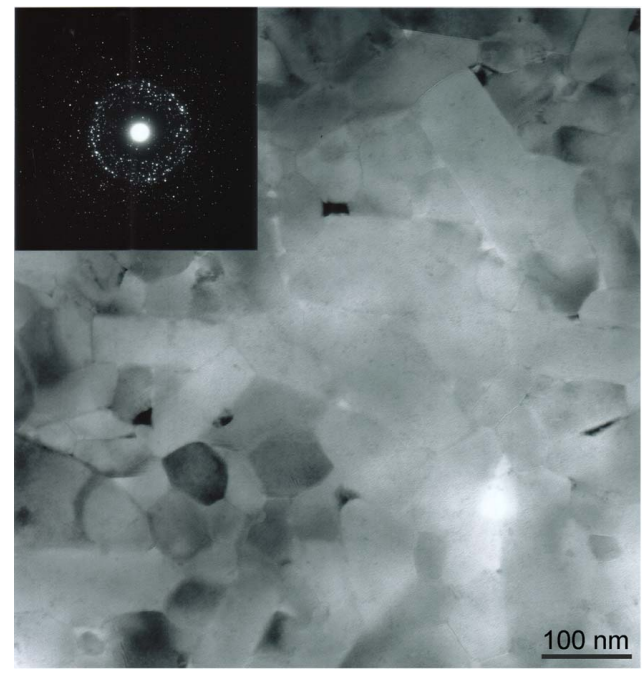

Fig. 10 TEM photograph and electron diffraction patterns of melt-spun $\mathrm{Di}_{12.5} \mathrm{Fe}_{69.8} \mathrm{Co}_{10} \mathrm{Nb}_{1} \mathrm{Y}_{0.7} \mathrm{~B}_{6}$ alloy ribbons annealed at $650^{\circ} \mathrm{C}$ for $10 \mathrm{~min}$.

Fig.9 は $\mathrm{Di}_{12.5} \mathrm{Fe}_{69.8} \mathrm{Co}_{10} \mathrm{Nb}_{1} \mathrm{Y}_{0.7} \mathrm{~B}_{6}$ 組成急冷薄帯の磁束 $\Phi$ と保磁力 $H_{\mathrm{c}}$ の $25 \sim 125^{\circ} \mathrm{C}$ までの温度特性を示している. 図から知られるよ うに， $\Phi, H_{\mathrm{c}}$ は温度の上昇とともに減少する傾向を示し， $\Phi$ の可 逆温度係数の平均は $\alpha(\Phi)$ ave $=-0.03 \%$ Cであった. 著者らの 報告であるDi12.5 $\mathrm{Fe}_{70.5} \mathrm{Co}_{10} \mathrm{Nb}_{1} \mathrm{~B}_{6}$ 組成急冷薄帯 7), 及び $\mathrm{Di}_{12.5} \mathrm{Fe}_{69.5} \mathrm{Co}_{10} \mathrm{Nb}_{1} \mathrm{~V}_{1} \mathrm{~B}_{6}$ 組成急冷薄帯8) での $\Phi$ の可逆温度係 数の平均はそれぞれ， $\alpha(\Phi)$ ave $=-0.03 \% / \mathrm{C}, \alpha(\Phi)$ ave $=-$ $0.04 \%$ \% ${ }^{\circ}$ であるので，それらと比較し本組成急冷薄帯では同等も しくは良好な值を得ている. また $H_{\mathrm{c} J}$ の温度係数は直線外挿で求め ると $\alpha\left(H_{c J}\right)=-0.46 \%$ Cであった. なお, $H_{c J}$ は各温度でパルス 着磁後, 減磁曲線を測定した值より算出した.

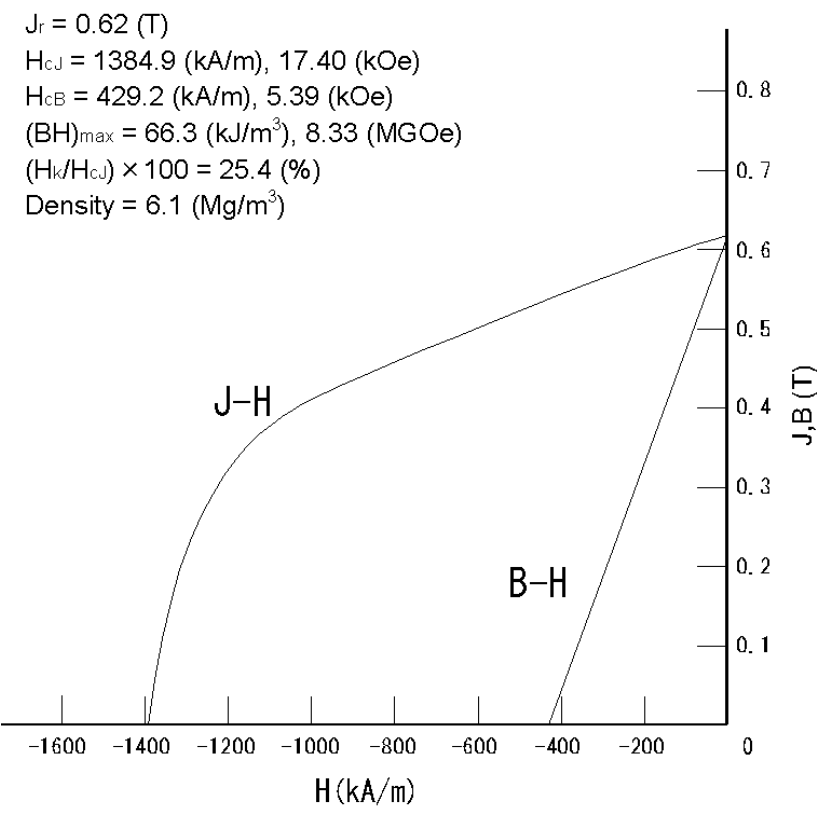

Fig. 11 Demagnetization curves for the isotropic compression molding Di12.5Fe69.8 $\mathrm{Co}_{10} \mathrm{Nb}_{1} \mathrm{Y}_{0.7} \mathrm{~B}_{6}$ bonded magnet. 
Table 1 Magnetic properties of the isotropic compression molding Di12.5Fe69.8 $\mathrm{Co}_{10} \mathrm{Nb}_{1} \mathrm{Y}_{0.7} \mathrm{~B}_{6}, \mathrm{MQP}-\mathrm{O}$, and $\mathrm{Di}_{12.5} \mathrm{Fe}_{70.5} \mathrm{Co}_{10} \mathrm{Nb}_{1} \mathrm{~B}_{6}$ bonded magnets.

\begin{tabular}{l|c|c|c|c|c|c}
\hline \multicolumn{1}{c|}{ Composition } & $\begin{array}{c}\mathrm{J}_{\mathrm{r}} \\
{[\mathrm{T}]}\end{array}$ & $\begin{array}{c}\mathrm{H}_{\mathrm{cJ}} \\
{[\mathrm{kA} / \mathrm{m}]}\end{array}$ & $\begin{array}{c}\mathrm{H}_{\mathrm{cB}} \\
{[\mathrm{kA} / \mathrm{m}]}\end{array}$ & $\begin{array}{c}(\mathrm{BH})_{\max } \\
{\left[\mathrm{kJ} / \mathrm{m}^{3}\right]}\end{array}$ & $\begin{array}{c}\text { Irreversible } \\
\left.\text { loss(125 }{ }^{\circ} \mathrm{C}\right) \\
{[\%]}\end{array}$ & $\begin{array}{c}\text { Irreversible } \\
\text { loss(150 } \\
{[\%]}\end{array}$ \\
\hline $\begin{array}{l}\mathrm{Di}_{12.5} \mathrm{Fe}_{69.8} \mathrm{Co}_{10} \\
\mathrm{Nb}_{1} \mathrm{Y}_{0.7} \mathrm{~B}_{6}\end{array}$ & 0.62 & 1384.9 & 429.2 & 66.3 & -1.38 & -3.58 \\
\hline $\mathrm{MQP}-\mathrm{O}$ & 0.69 & 1049.2 & 464.6 & 79.1 & -1.53 & -4.50 \\
\hline $\begin{array}{l}\mathrm{Di}_{12.5} \mathrm{Fe}_{70.5} \mathrm{Co}_{10} \\
\mathrm{Nb}_{1} \mathrm{~B}_{6}\end{array}$ & 0.72 & 956.1 & 495.1 & 91.0 & -2.34 & - \\
\hline
\end{tabular}

次にDi12.5Fe69.8 $\mathrm{Co}_{10} \mathrm{Nb}_{1} \mathrm{Y}_{0.7} \mathrm{~B}_{6}$ 組成急冷薄帯のTEM写真及び電 子線回折図形をFig.10に示寸.電子線回折図形は電子ビーム径 700 $\mathrm{nm}$ のものである. 写真から知られるように結晶粒径は 15〜100 $\mathrm{nm}$ 程度のものが観察され，平均粒径は約 $48 \mathrm{~nm} ゙$ あった。 また, 電子線回折写真より, 本試料は等方性であることが確認された. 著者らの従来の報告における平均粒径は, $\mathrm{Di}_{12.5} \mathrm{Fe}_{70.5} \mathrm{Co}_{10} \mathrm{Nb}_{1} \mathrm{~B}_{6}$ 組成急冷薄帯では約 $20 \mathrm{~nm}, \mathrm{Di}_{12.5} \mathrm{Fe}_{69.5} \mathrm{Co}_{10} \mathrm{Nb}_{1} \mathrm{~V}_{1} \mathrm{~B}_{6}$ 組成 急冷薄帯では約 $25 \mathrm{~nm}$ である. それらと比べ本組成急冷薄帯の 粒径は大きいので保磁力の増大寸る原因にはなりにくい. 前述の ように化合物の磁気の本質的な特性 $\left(\mathrm{H}_{\mathrm{A}}, \mathrm{K}_{\mathrm{A}}\right)$ の絶対值が変化し ているものと思われる. しかし，等方性であるためはっきりとし たことは明らかでない.

\section{3 ボンド磁石の磁気特性及び温度特性}

Fig.11 に最適条件で急冷, 熱処理を行った急冷薄帯を用い作製 した代表的な等方性圧縮成形ボンド磁石の減磁曲線を示す. ボン ド磁石の密度は $6.1 \mathrm{Mg} / \mathrm{m}^{3}$ であった. また, 磁気特性は $J_{\mathrm{r}}=0.62 \mathrm{~T}$, $H_{\mathrm{cJ}}=1384.9 \mathrm{kA} / \mathrm{m}, H_{\mathrm{cB}}=429.2 \mathrm{kA} / \mathrm{m},(B H)_{\max }=66.3 \mathrm{~kJ} / \mathrm{m}^{3}$ を得 た. また角型比 $H_{\mathrm{k}} / H_{\mathrm{a}} \times 100=25.4 \%$ \%゙あった. これらボンド磁石 の磁気特性は急冷薄帯と比べ, 保磁力があまり低下していないの が特徵であり, 高保磁力のボンド磁石を作製することができた.

Table 1 に本実験で得られたDi ${ }_{12.5} \mathrm{Fe}_{69.8} \mathrm{Co}_{10} \mathrm{Nb}_{1} \mathrm{Y}_{0.7} \mathrm{~B}_{6}$ 組成ボン ド磁石と MQP-O ボンド磁石, そして Y 無添加の $\mathrm{Di}_{12.5} \mathrm{Fe}{ }_{70.5} \mathrm{Co}_{10} \mathrm{Nb}_{1} \mathrm{~B}_{6}$ 組成ボンド磁石の磁気特性について示す. MQP-Oボンド磁石はMagnequench社のNd-Fe-Nb-B系等方性磁 性粉末であるMQP-O 10)を用い，同条件で作製したものである.

さらにFig.12にはこれらボンド磁石の不可逆減磁率を示 す. 不可逆減磁率はボンド磁石の $25 \sim 150^{\circ} \mathrm{C}$ ま゙の磁束の 温度依存性を表したものであり, 磁束はボンド磁石を 4.8 $\mathrm{MA} / \mathrm{m}$ でパルス着磁した後, 恒温槽中にて所定の温度で 1 時間保持し，大気中で 1 時間冷却したものを常温でデジタ ルフラックスメータを用いて測定した。この結果,

$\mathrm{Di}_{12.5} \mathrm{Fe}_{69.8} \mathrm{Co}_{10} \mathrm{Nb}_{1} \mathrm{Y}_{0.7} \mathrm{~B}_{6}$ 組成ボンド磁石の磁束の不可逆 減磁率は, $125^{\circ} \mathrm{C} て ゙ ー 1.38 \%, 150^{\circ} \mathrm{C}$ でー $3.58 \%$ となった. これに対しMQP-Oボンド磁石の磁束の不可逆減磁率は, $125^{\circ} \mathrm{C}$ でー $1.53 \%, 150^{\circ} \mathrm{C}$ でー $4.50 \%$ であった. 以上のこ とより MQP-Oボンド磁石と比較して良好な值を示し, 耐熱 性が改善されたことがわかる。また，Y無添加の $\mathrm{Di}_{12.5} \mathrm{Fe}_{70.5} \mathrm{Co}_{10} \mathrm{Nb}_{1} \mathrm{~B}_{6}$ 組成ボンド磁石と比較すると, Y添加

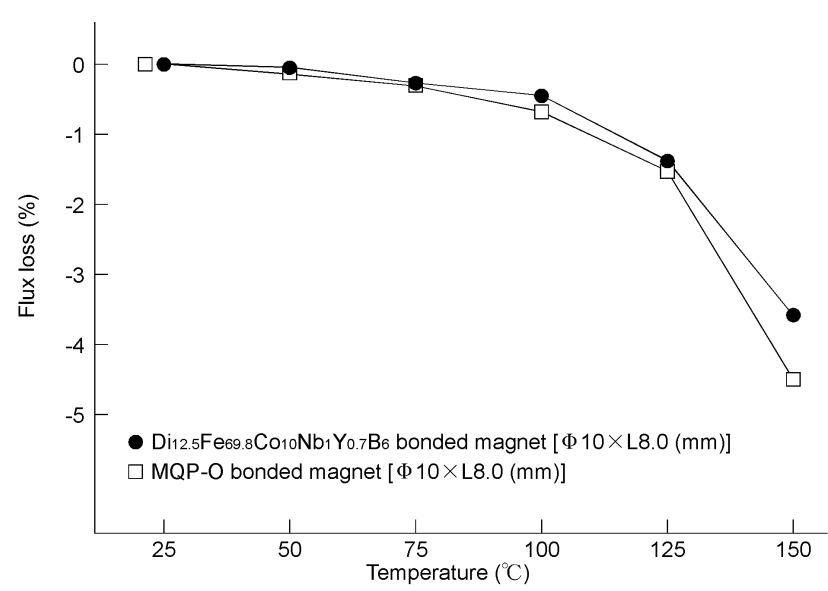

Fig. 12 Temperature dependence of the irreversible loss for the isotropic compression molding $\mathrm{Di}_{12.5} \mathrm{Fe}_{69.8} \mathrm{Co}_{10}$ $\mathrm{Nb}_{1} \mathrm{Y}_{0.7} \mathrm{~B}_{6}$ and $\mathrm{MQP}-\mathrm{O}$ bonded magnets.

により保磁力と温度特性が向上したことが見て取れる.

\section{4. 結言}

以上の実験・考察をまとめると次のようである.

1） $\mathrm{Di}_{12.5} \mathrm{Fe}_{70.5-\mathrm{x}} \mathrm{Co}_{10} \mathrm{Nb}_{1} \mathrm{Y}_{\mathrm{x}} \mathrm{B}_{6}$ 組成急冷薄帯において，良好 な磁気特性が得られた試料の組成並びに作製条件以下のと おりである．組成 : $\mathrm{Di}_{12.5} \mathrm{Fe}_{69.8} \mathrm{Co}_{10} \mathrm{Nb}_{1} \mathrm{Y}_{0.7} \mathrm{~B}_{6}$, ロール周速 度 : $20.0 \mathrm{~m} / \mathrm{s}$, 熱処理温度 : $650^{\circ} \mathrm{C}$, 熱処理時間 : $10 \mathrm{~min}$, このときの磁気特性は， $J_{\mathrm{r}}=0.85 \mathrm{~T}, H_{\mathrm{cJ}}=1409.0 \mathrm{kA} / \mathrm{m}$, $H_{\mathrm{cB}}=588.3 \mathrm{kA} / \mathrm{m},(B H)_{\text {max }}=126.4 \mathrm{~kJ} / \mathrm{m}^{3}$, 角型比 $H_{\mathrm{k}} / H_{\mathrm{cJ}} \times 100=31.9 \%$ ，キュリー温度 $T_{\mathrm{c}}=428^{\circ} \mathrm{C}$ であった. また， $\Phi$ の可逆温度係数の平均 $\alpha(\Phi)$ ave $=-0.03 \% /{ }^{\circ} \mathrm{C}$, $H_{\mathrm{cJ}}$ の温度係数 $\alpha\left(H_{c J}\right)=-0.46 \% /{ }^{\circ} \mathrm{C}$ であった.

2) $\mathrm{Di}_{12.5} \mathrm{Fe}_{69.8} \mathrm{Co}_{10} \mathrm{Nb}_{1} \mathrm{Y}_{0.7} \mathrm{~B}_{6}$ 組成において，最適作製条件 で作製した薄帯を用いて作製した代表的な等方性圧縮成形 ボンド磁石の磁気特性は, $J_{\mathrm{r}}=0.62 \mathrm{~T}, H_{\mathrm{cJ}}=1384.9 \mathrm{kA} / \mathrm{m}$, $H_{\mathrm{cB}}=429.2 \mathrm{kA} / \mathrm{m},(B H)_{\text {max }}=66.3 \mathrm{~kJ} / \mathrm{m}^{3}$, 角型比 $H_{\mathrm{k}} / H_{\mathrm{cJ}} \times 100=25.4 \%$ ，また密度は $6.1 \mathrm{Mg} / \mathrm{m}^{3}$ であった。

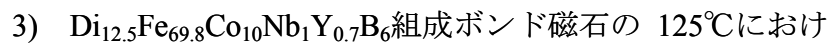
る磁束の不可逆減磁率は－1.38\%, $150^{\circ} \mathrm{C}$ ではー3.58\%で

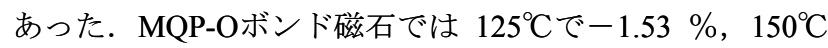
でー4.50\%であった. 本組成ボンド磁石はMQP-Oボンド磁 石と比較して良好な值を得ることができた. 
以上のように $\mathrm{Di}_{12.5} \mathrm{Fe}_{69.8} \mathrm{Co}_{10} \mathrm{Nb}_{1} \mathrm{Y}_{0.7} \mathrm{~B}_{6}$ 組成ボンド磁石は, $\mathrm{Y}$ の少量添加の効果により, Y無添加に比べ保磁力が約 $45 \%$ 増加し, 耐熱性の優れたボンド磁石の作製が可能となった.

謝辞 本研究は, 平成 16 年度文部科学省科学研究補助金基 盤研究 B（課題番号:16360159）によることを記し，また Didymium-Fe 合金をご提供いただいた(株)三徳の岡田 カ 氏，並びに山本 和彦氏に深く感謝致します.

\section{References}

1) J.J.Croat, J.F.Herbst, R.W.Lee, and F.E.Pinkerton: J. App. Phys., 55, p.2078(1984)

2) H.Yamamoto, M.Nagakura, Y.Ozawa, and T.Katsuno: IEEE Trans. Magn., 25, p.4123(1989)
3) R.Coehoorn, D.B.De.Mooji, and C.De.Ward: J. Magn. Mat., 80, p.101(1989)

4) S.Hirosawa, H.Kanekiyo, and M.Uehara: J. Appl. Phys., 73, 6488(1993)

5) A.Inoue, A.Takeuchi, A.Makino, and T.Mastumoto: IEEE Trans. Magn., 31, p.3626(1995)

6) H.Yamamoto and T.Yamane: J. Magn. Soc. Jpn, 25, p.1405(2001)

7) H.Yamamoto, and N.Adachi: Proceedings of 2002 Annual Conference of Fundamentals and Materials Society IEE Japan, IV -04, p.164(2002)

8) H.Yamamoto and K.Furusawa: Proceedings of 2004 Annual Conference of Fundamentals and Materials Society IEE Japan, III -01, p.27 (2004)

9) K.Furusawa and H.Yamamoto: IEEE Trans. Magn., 41, No.10(2005), to be published.

10) Catalogue of Magnequench International, INC. http://www.magnequench.com/products/index_powders.htm (As of June 10, 2005)

2005年10月19日受理，2006年1月16日採録 